\title{
Performance of Tomato (Solanum lycopersicum L.) Hybrids for Yield and its Contributing Traits under Mid-hill Conditions of Himachal Pradesh
}

\author{
Tanvi Raj ${ }^{1}$, Madan Lal Bhardwaj ${ }^{2}$, Saheb Pal ${ }^{3 *}$ Santosh Kumari ${ }^{4}$ and Rajesh Kumar Dogra ${ }^{5}$
}

\author{
${ }^{1}$ Dept. of Vegetable Science, ${ }^{5}$ Dept. of Fruit Science, Dr. Y. S. Parmar University of Horticulture and Forestry, Nauni, Solan, \\ Himachal Pradesh (173 230), India \\ ${ }^{2}$ Regional Horticultural Research and Training Station, Dr. Y. S. Parmar University of Horticulture and Forestry, Jachh, Kangra, \\ Himachal Pradesh (176 202), India \\ ${ }^{3}$ Division of Vegetable Crops, ICAR- Indian Institute of Horticultural Research, Hesaraghatta, Bengaluru, Karnataka (560 089), India \\ ${ }^{4} \mathrm{KVK}$, Chamba, Dr. Y. S. Parmar University of Horticulture and Forestry, Chamba, Himachal Pradesh (176 310), India
}

\section{Corresponding Author}

Saheb Pal

e-mail: saheb.horti@gmail.com

\author{
Article History \\ Article ID: AR1862 \\ Received in $11^{\text {th }}$ February, 2018 \\ Received in revised form $20^{\text {th }}$ March, 2018 \\ Accepted in final form $05^{\text {th }}$ April, 2018
}

\begin{abstract}
With an objective to estimate the performance of tomato hybrids with respect to their yield and yield contributing traits, an experiment was conducted at the experimental farm of RHR\&TS, Jachh, Kangra, Himachal Pradesh with 20 hybrids along with their 12 diverse parents and standard check Naveen 2000+, which is a leading commercial tomato hybrid in Himachal Pradesh. The hybrids were produced during Rabi 2015 by following linextester mating design and were evaluated during kharif, 2016. The later experiment was designed in Randomized Complete Block Design (RCBD) with three replications. The obtained results revealed that the hybrid, EC-620410×Solan Lalima was earliest among all the entries in terms of days to $50 \%$ flowering, while both the hybrids between EC- 8910155 and FT-5 were earliest in terms of days taken to marketable maturity. The hybrid between BT-1-1 $\times$ FT-5 had maximum number of fruits cluster ${ }^{1}$ as well as maximum yield plant $^{1}$. For average fruit weight, the hybrids of BT-1-1×Solan Lalima were found best among all the hybrids and their parents. The hybrid, LE-79-5 xFT-5 produced maximum number of marketable fruits plant ${ }^{1}$. Moreover this hybrid recorded minimum severity of Alternaria blight (early blight). Hence, for commercial exploitation of heterosis for earliness and yield in tomato, these hybrids are needed to be tested in multiple locations for stability before releasing as varieties.
\end{abstract}

Keywords: Tomato, hybrids, performance, mid-hills, linextester

\section{Introduction}

Tomato, Solanum lycopersicum L., a member of family Solanaceae, is one of the most important, popular and widely grown vegetable crop in the world. The crop is mainly valued for its mature fruits which are eaten fresh as salad and also processed into several products like puree, paste, ketchup or whole canned fruits. Owing to its nutritional value and antioxidant properties, due to presence of lycopene and flavanoides, tomato is universally treated as 'protective food' (Sepat et al., 2013).

Although India is second largest producer of tomato just after China, our national productivity $\left(21.2 \mathrm{t} \mathrm{ha}^{-1}\right)$ is far lower than that of world average (33.99 t ha-1) (Anonymous, 2015). One of the main reasons for this might be due to less exploitation of the genetic potential of this crop by heterosis breeding. To minimize the gap of productivity of this crop, there is an urgent need to come up with desirable and superior hybrid varieties suited for different agro-ecological zones of India. Keeping in view these facts, the present experiment was formulated to develop superior tomato hybrids by involvingten diverse lines and two testers.

\section{Materials and Methods}

The present experiment was conducted at the Experimental Research Farm, RHR\&TS, Jachh, Kangra, Himachal Pradesh. During rabi, 2015, twenty crosses were made in a linextester fashion (Kempthorne, 1957) involving ten diverse lines viz. EC8910155, EC-191531, EC-191535, EC-620410, EC-174913, EC267727, EC-37239, LE-79-5, Yalabingo, BT-1-1and two testers viz. Solan Lalima and FT-5, procured from different sources and are being maintained at Department of Vegetable Science, Dr. Y.S. Parmar University of Horticulture and Forestry, Nauni, Solan, Himachal Pradesh. The parents and their 20hybrids along with a standard check variety, Naveen $2000+$, which is the leading commercial hybrid in Himachal Pradesh, were 
evaluated in a Randomized Complete Block Design (RCBD) with three replications during kharif, 2016. The row to row and plant to plant spacing was $90 \mathrm{~cm}$ and $30 \mathrm{~cm}$ respectively keeping twenty plants plot ${ }^{-1}\left(2.7 \times 2.0 \mathrm{~m}^{2}\right)$ in each entry in each replication. Standard cultural practices for raising healthy crop of tomato were followed (Anonymous, 2013).

Observations were recorded from five randomly selected plants (for plant characters) and from ten random fruits (for fruit characters), selected from the third harvest from each entry in each replication for traits viz., days to $50 \%$ flowering, days to marketable maturity, number of fruits cluster ${ }^{-1}$, number of marketable fruits plant ${ }^{-1}$, average fruit weight (g), plant height $(\mathrm{cm})$, harvest duration (days), Alternaria blight severity (\%) and fruit yield plant ${ }^{-1}(\mathrm{~g})$. Alternaria blight severity was recorded from 10 randomly selected leaves in each five random plants in each entry by adopting 0-5 scale (Shekhawat and Chakarvarti, 1974), where, grade 0 indicated $0 \%$ infected leaf area and 5 implied more than $75.1 \%$ infected leaf area. The Percent Disease Index (PDI) was calculated according to the following formula (McKinney, 1923),

PDI of Alternaria (\%)=Sum of all disease ratings/ (Total number of ratings $\times$ Highest disease grade)

The recorded data was subjected to analysis by MS-EXCEL and OPSTAT software (Sheron et al., 1998).

\section{Results and Discussion}

The analysis of variance (Table 1) showed significant variations in the parents as well as in their hybrids for all the traits under study.

The perusal of data, as presented in Table 2 revealed that, among the parents, days taken to $50 \%$ flowering ranged from 30.00 (EC-620410) to 34.67 days in both EC-37239and FT-5. Among the crosses, the values ranged from 26.33 (EC-620410 $\times$ Solan Lalima) to 34.67 days (YalabingoxSolan Lalima).Former hybrid was statistically at par ( $p \leq 0.05)$ with BT-1-1×FT-5(26.67) and EC-191531×FT-5 (26.67). This is an important horticultural trait which helps to determine the earliness of the genotype. Therefore negative heterosis is desired here. Out of the 20 resultant hybrids, 13 hybrids were found to be better than the standard check (33.00). Earlier, Kumari and Sharma (2011), Singh et al. (2012); Patwary et al. (2013) also found similar estimates for this trait while evaluating tomato hybrids. Days to marketable maturity are also a key determining factor of earliness which fetches remunerative returns to the farmers. The estimates ranged from 67.33 (EC-8910155) to 74.33 (Yalabingo and FT-5) among the parents. Among the hybrids, EC-8910155 × FT-5 took minimum (59.67) and EC191531×Solan Lalima (67.67) took maximum number of days to reach first harvest. All the 20 crosses showed desirable negative standard heterosis for this trait. Number of fruits cluster $^{-1}$ is an important yield determining trait in tomato as significant positive association of yield is often observed with this trait. In our study, among the parents, EC-174913 had maximum (5.53) and EC-37239 had minimum (3.90) number of fruits cluster ${ }^{-1}$, whereas, among the hybrids, BT-1-1 $\times$ FT- 5 had maximum (6.93) whereas, EC-620410 × FT-5 had minimum

\begin{tabular}{|c|c|c|c|c|}
\hline \multirow{2}{*}{$\begin{array}{l}\text { Characters/ } \\
\text { sources of } \\
\text { variation }\end{array}$} & \multicolumn{4}{|c|}{ Mean sum of squares } \\
\hline & $\begin{array}{l}\text { Repli- } \\
\text { cations }\end{array}$ & Genotypes & Error & Total \\
\hline $\begin{array}{l}\text { Degrees of } \\
\text { Freedom }\end{array}$ & 2 & $32^{*}$ & 64 & 98 \\
\hline $\begin{array}{l}\text { Days to } 50 \% \\
\text { flowering }\end{array}$ & 1.45 & $19.38^{*}$ & 0.57 & 21.41 \\
\hline $\begin{array}{l}\text { Days to mar- } \\
\text { ketable ma- } \\
\text { turity }\end{array}$ & 3.12 & $58.67^{*}$ & 0.29 & 62.08 \\
\hline $\begin{array}{l}\text { No. of fruits } \\
\text { cluster }^{-1}\end{array}$ & 0.03 & $1.16^{*}$ & 0.02 & 1.22 \\
\hline $\begin{array}{l}\text { No. of mar- } \\
\text { ketable fruits } \\
\text { plant }^{-1}\end{array}$ & 0.46 & $35.92^{*}$ & 0.24 & 36.62 \\
\hline $\begin{array}{l}\text { Average fruit } \\
\text { weight }(\mathrm{g})\end{array}$ & 1.73 & $205.47^{*}$ & 0.55 & 207.76 \\
\hline $\begin{array}{l}\text { Fruit yield } \\
\text { plant }^{-1}(\mathrm{~g})\end{array}$ & 291.92 & $134700.25^{*}$ & 472.13 & 135464.30 \\
\hline $\begin{array}{l}\text { Plant height } \\
\text { (cm) }\end{array}$ & 0.17 & $1197.74^{*}$ & 1.73 & 1199.64 \\
\hline $\begin{array}{l}\text { Harvest dura- } \\
\text { tion (days) }\end{array}$ & 0.28 & $7.06^{*}$ & 0.42 & 7.76 \\
\hline $\begin{array}{l}\text { Alternaria } \\
\text { blight severity } \\
\text { (\%) }\end{array}$ & 76.69 & $126.68^{*}$ & 22.14 & 225.51 \\
\hline
\end{tabular}

*Significant $(p \leq 0.05)$

(4.07) number of fruits cluster ${ }^{-1} .18$ hybrids were found superior than that of the standard check (4.13) with respect to this trait. Among the parents, LE-79-5 gave highest (20.83) and EC-191531 (12.53) gave lowest, whereas, the hybrid LE-795xFT-5 gave highest (28.50) and EC-37239×Solan Lalima gave lowest (12.33) number of marketable fruits plant ${ }^{-1}$. Four cross combinations were found superior over Naveen 2000+ (19.87) for this trait. These results are in line with that of Patwary et al. (2013); Ahmad et al. (2015); Kumar and Singh (2016). For average fruit weight, among the parents, EC-191535 had highest (69.08) and EC- 620410 had lowest (51.37), whereas, among the crosses, average fruit weight was highest ( $85.58 \mathrm{~g}$ ) in BT-1-1×Solan Lalima and was minimum ( $52.33 \mathrm{~g}$ ) in LE-79$5 \times$ Solan Lalima. Exactly half of the hybrids were found better than the standard check $(68.58 \mathrm{~g})$ with respect to this trait. Fruit weight is generally considered as the direct contributor of fruit yield. Similar results have also been noted by Ahmed et al. (2011); Agarwal et al. (2014).

The ultimate goal of any breeding programme is to achieve maximum marketable yield. For this trait, wide variation was recorded from $776.67 \mathrm{~g}$ (EC-191531) to $1220 \mathrm{~g}$ (LE-79-5). Among the hybrids, BT-1-1 $\times$ FT-5 had highest (1676.67 g) and EC-620410 $\times$ Solan Lalima had lowest $\left(913.33 \mathrm{~g}\right.$ ) yield plant ${ }^{-1}$ 


\begin{tabular}{|c|c|c|c|c|c|}
\hline Genotypes & $\begin{array}{l}\text { Days to } 50 \% \\
\text { Flowering }\end{array}$ & $\begin{array}{l}\text { Days to market- } \\
\text { able maturity }\end{array}$ & $\begin{array}{l}\text { No. of fruits } \\
\text { cluster }^{-1}\end{array}$ & $\begin{array}{l}\text { Marketable } \\
\text { fruits plant }^{-1}\end{array}$ & $\begin{array}{c}\text { Average fruit } \\
\text { weight (g) }\end{array}$ \\
\hline BT-1-1 & 33.67 & 72.67 & 4.07 & 16.13 & 62.47 \\
\hline EC-37239 & 34.67 & 70.67 & 3.90 & 13.50 & 60.83 \\
\hline EC-191535 & 33.33 & 70.67 & 4.40 & 16.43 & 69.08 \\
\hline EC-8910155 & 30.67 & 67.33 & 4.33 & 15.60 & 56.63 \\
\hline EC-174913 & 33.67 & 71.33 & 5.53 & 17.83 & 65.17 \\
\hline EC-191531 & 32.33 & 73.67 & 4.73 & 12.53 & 61.45 \\
\hline Yalabingo & 33.67 & 74.33 & 5.07 & 13.60 & 63.50 \\
\hline EC-267727 & 30.67 & 70.33 & 4.53 & 15.63 & 62.33 \\
\hline LE-79-5 & 30.67 & 70.67 & 4.93 & 20.83 & 57.80 \\
\hline EC-620410 & 30.00 & 72.00 & 4.23 & 19.70 & 51.37 \\
\hline FT-5 & 34.67 & 74.33 & 4.73 & 15.60 & 58.58 \\
\hline Solan Lalima & 33.33 & 72.33 & 5.10 & 18.63 & 55.58 \\
\hline BT-1-1×FT-5 & 26.67 & 61.67 & 6.93 & 22.80 & 70.83 \\
\hline BT-1-1×Solan Lalima & 30.67 & 63.33 & 4.33 & 15.13 & 85.58 \\
\hline EC-37239×FT-5 & 33.00 & 62.33 & 4.83 & 15.07 & 72.97 \\
\hline EC-37239×Solan Lalima & 32.33 & 66.67 & 4.90 & 12.33 & 80.75 \\
\hline EC-191535×FT-5 & 34.33 & 67.33 & 4.57 & 16.80 & 71.92 \\
\hline EC-191535×Solan Lalima & 28.67 & 61.33 & 5.13 & 18.67 & 79.08 \\
\hline EC-8910155×FT-5 & 30.00 & 59.67 & 4.93 & 21.00 & 60.95 \\
\hline EC-8910155×Solan Lalima & 28.33 & 67.33 & 4.93 & 18.40 & 68.83 \\
\hline EC-174913×FT-5 & 30.33 & 60.67 & 5.17 & 15.60 & 69.50 \\
\hline EC-174913×Solan Lalima & 33.00 & 66.00 & 5.73 & 15.20 & 66.58 \\
\hline EC-191531×FT-5 & 26.67 & 67.33 & 4.60 & 15.20 & 77.00 \\
\hline EC-191531× Solan Lalima & 33.00 & 67.67 & 4.93 & 16.60 & 70.58 \\
\hline YalabingoxFT-5 & 33.67 & 63.67 & 5.43 & 17.27 & 68.67 \\
\hline YalabingoxSolan Lalima & 34.67 & 66.33 & 5.63 & 18.73 & 74.08 \\
\hline EC-267727×FT-5 & 30.33 & 67.33 & 5.87 & 20.00 & 62.00 \\
\hline EC-267727×Solan Lalima & 31.00 & 67.33 & 4.60 & 17.53 & 70.58 \\
\hline LE-79-5×FT-5 & 28.33 & 60.33 & 5.17 & 28.50 & 56.53 \\
\hline LE-79-5×Solan Lalima & 28.67 & 61.67 & 5.43 & 25.40 & 52.33 \\
\hline EC-620410×FT-5 & 27.67 & 66.67 & 4.07 & 18.07 & 60.75 \\
\hline EC- $620410 \times$ Solan Lalima & 26.33 & 60.67 & 5.03 & 15.77 & 56.83 \\
\hline Naveen 2000+ & 33.00 & 68.33 & 4.13 & 19.87 & 68.58 \\
\hline SEd \pm & 0.62 & 0.44 & 0.12 & 0.40 & 0.61 \\
\hline $\mathrm{CD}(p=0.05)$ & 1.22 & 0.86 & 0.24 & 0.79 & 1.19 \\
\hline
\end{tabular}

(Table 3). Four cross combinations were found superior than the standard check (1350 g) for this trait. Similar estimates for this trait were also reported by Singh and Sastry, (2011) and Kumar and Singh (2016). Plant height is one of the most important factors that determines the harvest duration of the indeterminate tomatoes. Among the parents, Solan Lalima had maximum plant height $(154.63 \mathrm{~cm})$ and LE-79-5 had minimum $(67.33 \mathrm{~cm})$ plant height whereas, among the hybrids, maximum $(134.66 \mathrm{~cm})$ plant height was recorded in EC-174913 $\times$ FT-5, which was statistically at par $(p \leq 0.05)$ with 


\begin{tabular}{|c|c|c|c|c|}
\hline Genotypes & Fruit yield plant $^{-1}(\mathrm{~g})$ & Plant height $(\mathrm{cm})$ & $\begin{array}{l}\text { Harvest duration } \\
\text { (days) }\end{array}$ & $\begin{array}{l}\text { Severity of Alter- } \\
\text { naria blight (\%) \# }\end{array}$ \\
\hline BT-1-1 & 1010.00 & 95.33 & 29.33 & $15.55(23.12)$ \\
\hline EC-37239 & 820.00 & 70.33 & 29.67 & $35.55(36.57)$ \\
\hline EC-191535 & 1143.33 & 100.46 & 28.67 & $20.00(26.35)$ \\
\hline EC-8910155 & 876.67 & 91.44 & 32.33 & $28.89(32.47)$ \\
\hline EC-174913 & 1163.33 & 101.90 & 30.67 & $31.11(33.86)$ \\
\hline EC-191531 & 776.67 & 97.44 & 30.67 & 37.78 (37.89) \\
\hline Yalabingo & 886.67 & 77.56 & 34.33 & $26.67(30.96)$ \\
\hline EC-267727 & 986.67 & 83.20 & 31.33 & $31.11(33.86)$ \\
\hline LE-79-5 & 1220.00 & 67.33 & 33.67 & $24.45(29.57)$ \\
\hline EC-620410 & 1040.00 & 94.91 & 29.67 & $22.22(28.06)$ \\
\hline FT-5 & 920.00 & 122.11 & 31.33 & $24.45(29.57)$ \\
\hline Solan Lalima & 1036.67 & 154.63 & 32.67 & $28.89(32.47)$ \\
\hline BT-1-1 × FT-5 & 1676.67 & 125.14 & 34.33 & $13.33(20.97)$ \\
\hline BT-1-1 × Solan Lalima & 1300.00 & 120.39 & 33.33 & $20.00(26.35)$ \\
\hline EC-37239×FT-5 & 1123.33 & 133.58 & 33.33 & $26.67(30.96)$ \\
\hline EC-37239×Solan Lalima & 1026.67 & 110.65 & 33.67 & $35.55(36.57)$ \\
\hline EC-191535×FT-5 & 1226.67 & 126.18 & 33.33 & $20.00(26.35)$ \\
\hline EC-191535×Solan Lalima & 1480.00 & 123.37 & 32.33 & $24.45(29.57)$ \\
\hline EC-8910155×FT-5 & 1273.33 & 94.55 & 33.00 & $20.00(26.35)$ \\
\hline EC-8910155×Solan Lalima & 1233.33 & 108.77 & 33.33 & $22.22(28.06)$ \\
\hline EC-174913×FT-5 & 1086.67 & 134.66 & 32.33 & $24.45(29.57)$ \\
\hline EC-174913×Solan Lalima & 990.00 & 124.36 & 32.33 & $28.89(32.47)$ \\
\hline EC-191531×FT-5 & 1146.67 & 115.56 & 33.67 & $26.67(30.96)$ \\
\hline EC-191531× Solan Lalima & 1180.00 & 121.55 & 33.00 & $28.89(32.47)$ \\
\hline Yalabingo $\times F T-5$ & 1196.67 & 124.92 & 33.33 & $26.67(30.96)$ \\
\hline YalabingoxSolan Lalima & 1400.00 & 120.62 & 34.33 & $20.00(26.35)$ \\
\hline EC-267727×FT-5 & 1253.33 & 100.38 & 32.00 & $15.55(23.12)$ \\
\hline EC-267727×Solan Lalima & 1213.33 & 123.74 & 31.33 & $31.11(33.86)$ \\
\hline LE-79-5×FT-5 & 1620.00 & 102.70 & 33.00 & $11.11(19.26)$ \\
\hline LE-79-5×Solan Lalima & 1333.33 & 114.28 & 33.67 & $24.45(29.57)$ \\
\hline EC-620410×FT-5 & 1103.33 & 96.95 & 31.67 & $28.89(32.47)$ \\
\hline EC-620410×Solan Lalima & 913.33 & 97.45 & 32.33 & 35.55 (36.57) \\
\hline Naveen $2000+$ & 1350.00 & 138.43 & 34.33 & $22.22(28.06)$ \\
\hline SEd \pm & 17.74 & 1.07 & 0.53 & 2.70 \\
\hline $\mathrm{CD}(p=0.05)$ & 34.77 & 2.11 & 1.03 & 5.41 \\
\hline
\end{tabular}

EC-267727×FT-5 $(133.58 \mathrm{~cm})$. Minimum plant height $(94.55$ $\mathrm{cm}$ ) was recorded in EC-8910155×FT-5. However, none of the hybrids could exceed the plant height of Solan Lalima. Similar estimates were also reported by Kumar et al. (2009) and Kumari et al. (2010). Genotypes with longer harvest duration are preferred as these ensure continuous supply of produce over a longer period of time. It is also one of the key determining factors for the acceptability of a variety among the farmers. Among the parents, maximum harvest duration was recorded in Yalabingo (34.33 days), while minimum was 
recorded in EC-191535 (28.67 days) among the parents, while, maximum harvest duration (34.33 days) was recorded in both YalabingoxSolan Lalima and BT-1-1×FT-5 which was equal to the harvest duration of the line Yalabingo, while minimum harvest duration (31.33 days) was recorded in EC$267727 \times$ Solan Lalima. Similar estimates were also observed by Sharma and Thakur (2008); Kumari and Sharma (2011). The severity of Alternaria blight ranged from $15.55 \%$ (BT-11) to $37.78 \%$ (EC-191531) among the parents, while among the hybrids, blight severity was recorded minimum (11.11\%) in LE-79-5×FT-5 which was statistically at par $(p \leq 0.05)$ with two other hybrids. Maximum Alternaria blight severity (35.55\%) was recorded in both EC-37239×Solan Lalima and EC-620410xSolan Lalima. Two hybrids were found better than the standard check, Naveen 2000+ with respect to this trait (22.22\%). Earlier, Liu et al.(2004) and Mate et al. (2005) found that Alternaria blight in tomato and found that disease severity varied with the genotype and environmental interactions.

\section{Conclusion}

Yield improvement is the first and foremost objective in any crop breeding programme. The national productivity of tomato in India is much lesser than that of the world average. Finding a high yielding variety with disease tolerance or resistance is the way to minimize this productivity gap. Hence, the desirable hybrids, as reported in this study, may be tested in multiple locations before their release.

\section{Acknowledgement}

The authors are thankful to all the staffs of RHR\&TS, Jacch, Kangra, Himachal Pradesh for providing all the necessary facilities during the research trials.

\section{References}

Agarwal, A., Arya, D.N., Ranjan, R., Ahmed, Z., 2014. Heterosis, combining ability and geneaction for yield and quality traits in tomato (Solanum lycopersicum L.). Helix, 2, 511-515.

Ahmad, M., Gul, Z., Khan, Z.U., Iqbal, M., Khan, B., Saleem, M., Ullah, I., 2015. Study ofheterosis in different cross combinations of tomato for yield and yield components. International Journal of Biosciences 7(2), 12-15.

Ahmed, S., Quamruzzaman, A.K.M., Uddin, M.N., 2011. Estimate of heterosis in tomato (Solanum lycopersicum L.). Bangladesh Journal Agriculture Research,36(3), 521-527.

Anonymous, 2013. Package of Practices for Vegetable Crops. Directorate of Extension Education, Dr. Y.S. Parmar University of Horticulture and Forestry, Nauni, Solan, India, 202.

Anonymous, 2015. Handbook of Indian Horticulture Database, NHB, Gurgaon. Departmentof Agriculture and Cooperation, Ministry of Agriculture, Government of India, New Delhi, 48.

Kempthorne, O., 1957. An Introduction to Genetic Statistics. John Wiley and Sons Inc. New York, 458-471.

Kumar, C., Singh, S.P., 2016. Heterosis and inbreeding depression to identify superior $F_{1}$ hybrids in tomato (Solanum lycopersicum L.) for the yield and its contributing traits. Journal of Applied and Natural Science 8(1), 290-296.

Kumar, Y.K.H., Patil, S.S., Dharmatti, P.R., Byadagi, A.S., Kajjidoni, S.T., Patil, R.H., 2009. Estimation of heterosis for tospovirus resistance in tomato. Karnataka Journal ofAgricultural Sciences 22(5), 1073-1075.

Kumari, N., Srivastava, J.P., Singh, B., Deokaran., 2010. Heterotic expression for yield and itscomponents in tomato (Lycopersicon esculentum Mill). Annals of Horticulture 3(1), 98-101.

Kumari, S., Sharma, M.K., 2011. Exploitation of heterosis for yield and its contributing traitsin tomato (Solanum lycopersicum L.). International Journal of Farm Sciences 1(2), 45-55.

Liu, G., Li. J., Niu, X., 2004. A new tomato variety "Jinfanque No-5". China Vegetables 4, 24-25.

Mate, G.D., Deshmukh, V.V., Jiotode, D.J., Chore, N.S., Mayur, D., 2005. Screening of tomatocultivar for resistance to early blight. Research on Crops 6(2), 352-353.

McKinney, H.H., 1923. Influence of soil temperature and moisture on infection of wheat seedlings by Helminthosporium sativum. Journal of Agricultural Research 26, 195-217.

Patwary, Alam, M.M., Rahman, M.M., Shahabuddin, A., MiahKhaleque, M.A., Barua, H., 2013.Study on heterosis in heat tolerant tomato (Solanum lycopersicum) during summer.Bangladesh Journal of Agricultural Research 38(3), 531-544.

Sepat, N.K., Sepat, S.R., Sepat, S., Kumar, A., 2013. Energy use efficiency and cost analysis oftomato under greenhouse and open field production system at Nubra valley of Jammu andKashmir. International Journal of Environment Sciences 3(4), 1233-1241.

Sharma, D., Thakur, M.C., 2008. Evaluation of diallel progenies for yield and its contributingtraits in tomato under mid-hill conditions. Indian Journal of Horticulture 65(3), 297-301.

Shekhawat, P.S., Chakarvati, B.P., 1974. Factor affecting development of bacterial leaf spotof chillies caused by Xanthomonas vesicatoria. Indian Phytopathology 29, 393-397.

Sheoran, O.P., Tonk, D.S., Kaushik, L.S., Hasija, R.C., Pannu, R.S., 1998. Statistical software package for agricultural research workers. In:Hooda, D.S., Hasija, R.C. (Eds.), Recent Advances in Information Theory, Statistics and Computer Applications.. Department of Mathematics and Statistics, Chaudhary Charan Singh Haryana Agricultural University, Hisar, Haryana, 139-143.

Singh, J., Sastry, E.V.D., 2011. Heterosis and stress susceptibility index for fruit yield andcontributing traits in tomato (Lycopersicon esculentum). Indian Journal of Agricultural Sciences 81(10), 957-966.

Singh, N.B., Wani, S.H., Haribhushan, A., Nongthombam, R., 2012. Heterosis studies for yieldand its components in tomato (Solanum lycopersicum L.) under valley conditions of Manipur. Society for Plant Research 25(2), 257-265. 